\title{
Cruris Fracture among Child Patients in Dr. Hasan Sadikin General Hospital Bandung
}

\author{
Wenny Dwi Chandra, ${ }^{1}$ Yoyos Dias Ismiarto, ${ }^{2}$ Alwin Tahid, ${ }^{3}$ Nucki Nursjamsi Hidajat ${ }^{2}$ \\ ${ }^{1}$ Faculty of Medicine Universitas Padjadjaran, ${ }^{2}$ Department of Orthopaedic and Traumatology \\ Faculty of Medicine Universitas Padjadjaran/Dr. Hasan Sadikin General Hospital Bandung, \\ ${ }^{3}$ Department of Anatomy and Cell Biology Faculty of Medicine Universitas Padjadjaran
}

\begin{abstract}
Background: Cruris are lower extremity fractures commonly found in children. These dangerous fractures may alter the quality of life of the patients. This study was conducted to explore the characteristics of cruris fractures in children.

Methods: A descriptive cross-sectional study was performed by reviewing the medical records of children who were hospitalized at the Department of Orthopaedi and Traumatology, Dr. Hasan Sadikin General Hospital Bandung during 2010-2011.

Results: On two years study, 62 cases have been reported. Most cases occurred among senior high school group (37.1\%). Boys $(71.0 \%)$ have a higher rate of fractures than girls. Fractures most frequently occurred by traffic accidents (87.1\%). The fractures are mostly open (58.1\%). The common fracture site was tibia $(50.0 \%)$ rather than fibula (3.2\%) and the most frequent location was on the right side $(79.0 \%)$ and on the middle third of the leg (41.9\%). Majority of the patients went home in good condition $(79.0 \%)$.

Conclusion: Fractures are most frequently occurred in April because of high humidity. The causes and distribution of the fractures based on diagnosis were related to another study. Furthermore, additional studies are needed to explore the characteristics of cruris fracture among children, not only in certain hospital but also in Indonesia especially in West Java. [AMJ.2015;2(1):276-80]
\end{abstract}

Keywords: Characteristic, child, cruris, fractures

\section{Introduction}

Injury is an accident that causes someone's daily activity to be disturbed. ${ }^{1}$ Children are more vulnerable of experiencing injury than adults. Injury can lead to many cases, one of them is fracture. ${ }^{2}$

A percentage of fractures in children is $20.6 \%$ of all kinds of injuries. ${ }^{2}$ The most often injuries occurred at lower extremities in children aged 5-14 years old (46.7\%) and in children aged $1-4$ years old (43.3\%). ${ }^{1}$ Injuries and fracture of lower extremity mostly occur on cruris area (292 cases), followed by femur (142 cases), foot ( 90 cases), and hip ( 9 cases). ${ }^{3}$ Cruris area are mostly tibia and fibula. Tibia has a function as weight bearing bones. ${ }^{4}$

Child bones are more susceptible of experiencing fractures because they have less mineral and more vessels compared to adult bones. A pressure to child bones will create a heavier impact than adult bones on the same compression. ${ }^{5}$ The right preventive actions and treatment on fractures is very important. Treating without a right treatment will make bones grow imperfectly, therefore affecting the quality of life when the child grow older. ${ }^{2}$ In Indonesia, the Ministry of Health designed a guidebook to prevent accidents, even though in Indonesia fracture cases is not a prime priority in medicare or health treatment in public. ${ }^{2}$

According to the data and explanation above, characteristics of cruris fractures in children which will provide baseline data for prevention program and treatment of cruris fracture cases on children need to be explored. Therefore, this study aimed to explore these characteristics.

\section{Methods}

This was a cross-sectional descriptive study conducted in October 2012 using 62 medical record in child patients $(0-<18$ years old $)$ with

Correspondence: Wenny Dwi Chandra, Faculty of Medicine, Universitas Padjadjaran, Jalan Raya Bandung-Sumedang Km.21, Jatinangor, Sumedang, Indonesia, Phone: Phone : +62 85261216031 Email: wenny.dwichandra@gmail.com 
Wenny Dwi Chandra, Yoyos Dias Ismiarto, Alwin Tahid, Nucki Nursjamsi Hidajat: Cruris Fracture among Child 277 Patients in Dr. Hasan Sadikin General Hospital Bandung

Table 1 Cruris Fractures in Children Based on Ages and Gender

\begin{tabular}{lcc}
\hline & Frequency (f) & Percentage (\%) \\
\hline Age (years old) & & 3.2 \\
Pre-school (0-3 years old) & 2 & 3.2 \\
Kindergarten (4-5 years old) & 2 & 22.6 \\
Primary School (6-12 years old) & 14 & 33.9 \\
Junior High School (13-15 years old) & 21 & 37.1 \\
Senior High School (16-17 years old) & 23 & \\
Gender & & 71.0 \\
Male & 44 & 29.0 \\
Female & 18 & \\
\hline
\end{tabular}

cruris fractures at Department of Orthopaedi and Traumatology Dr. Hasan Sadikin General Hospital Bandung during 2010-2011.

The exclusion criteria are child patients with cruris fractures at Department of Orthopaedi and Traumatology at Dr. Hasan Sadikin General Hospital Bandung during 2010-2011 with incomplete data or missing medical record.

\section{Results}

From this study, 71 medical records were obtained, but only 62 data were appropriate with the selection criteria of the study.

Cruris Fracture in children kept rising along with the growth of those children and reach the peak when they reach group age of senior high school (16-17 years old) where there are 23 patients $(37.1 \%)$.

The number of cruris fractures is dominated by male with 44 patients $(71 \%)$. While female patients have a less number which was 18 patients $(29 \%)$. The ratio between male and female were 22:9.

Child patients with cruris fractures on 2010 was 35 patients $(56,5 \%)$ and decreased on 2011 as much as 27 patients (43.5\%). Fractures most frequently occurred on April with 10 patients $(16.1 \%)$ and followed by June with 8 patients $(12.9 \%)$.

Causes of cruris fracture in children were traffic accidents with 54 patients $(87.1 \%)$ and other minor factors which were working accidents and surgical complication, each of

Table 2 Cruris Fractures in Children Based on the Time of Occurrence

\begin{tabular}{lcccc}
\hline \multicolumn{1}{r}{ Month } & $\mathbf{2 0 1 0}$ & $\mathbf{2 0 1 1}$ & Frequency (f) & Percentage (\%) \\
\hline January & 3 & 2 & 5 & 8.1 \\
February & 2 & 1 & 3 & 4.8 \\
March & 1 & 1 & 2 & 3.2 \\
April & 5 & 5 & 10 & 16.1 \\
May & 3 & 2 & 5 & 8.1 \\
June & 2 & 6 & 8 & 12.9 \\
July & 4 & 1 & 5 & 8.1 \\
August & 3 & 2 & 5 & 8.1 \\
September & 2 & 2 & 4 & 6.4 \\
October & 4 & 1 & 5 & 8.1 \\
November & 1 & 3 & 4 & 6.4 \\
Desember & 5 & 1 & 6 & 9.7 \\
Total & 35 & 27 & 62 & 100.0 \\
\hline
\end{tabular}


Table 3 Cruris Fractures in Children Based on Causes of Fractures

\begin{tabular}{lcc}
\hline \multicolumn{1}{c}{ Causes of Fracture } & Frequency (f) & Percentage (\%) \\
\hline Traffic Accident & 1 & \\
Car Accidents & 43 & 1.6 \\
Motorcycle Accidents & 9 & 69.4 \\
Pedestrian Accidents & 1 & 14.5 \\
Without Information & & 1.6 \\
Falling & 3 & \\
Fall from high & 2 & 4.9 \\
Fall from motorcycle & 1 & 3.2 \\
Falling stumbled & 1 & 1.6 \\
Working accidents & 1 & 1.6 \\
Surgical Complication & & 1.6 \\
\hline
\end{tabular}

factor only have 1 patients (1.65\%).

Distribution of cruris fractures sufferer according to fractures diagnosis are divided based on: (1) Type of fractures, whether it was open or close; (2) Bones involved, whether only tibia, only fibula, or both of tibia and fibula; (3) Location of fracture, divided into right or left, distal, medial, or proximal.

The most often type of Cruris fractures was open fracture with 36 patients (58.1\%). Bones that very often get cruris fracture in children are tibia with 31 patients $(50.0 \%)$ and the less often are fibula with 2 patients (3.2\%). The most often fracture were located on the right side with 49 patients $(79.0 \%)$ and on the left side only 13 patients $(21.0 \%)$. Cruris fractures often occured on medial part of lower extremity as much as 26 patients $(41.9 \%)$

The most cruris fractures patient's condition when going home are getting better with 49 patients (79.0\%) followed by recovered patients with 3 patients $(4.8 \%)$

Table 4 Cruris Fractures in Children Based on Diagnosis

\begin{tabular}{lcc}
\hline & Frequency (f) & Percentage (\%) \\
\hline Type of Fracture & & \\
$\quad$ Close & 26 & 41.9 \\
Open & 36 & 58.1 \\
Fractured Bone(s) & & \\
$\quad$ Fibula & 2 & 3.2 \\
Tibia & 31 & 50.0 \\
Tibia; Fibula & 29 & 46.8 \\
Location (R/L) & & \\
Right & 49 & 79.0 \\
Left & 13 & 21.0 \\
Location (Distal/Medial/Proximal) & & \\
$\quad$ Distal & 17 & 27.4 \\
Medial & 26 & 41.9 \\
Proximal & 17 & 27.4 \\
Different Level & 2 & 3.2 \\
\hline
\end{tabular}


Wenny Dwi Chandra, Yoyos Dias Ismiarto, Alwin Tahid, Nucki Nursjamsi Hidajat: Cruris Fracture among 279 Child Patients in Dr. Hasan Sadikin General Hospital Bandung

Table 5 Cruris Fractures in Children Based on discharge from hospital

\begin{tabular}{|c|c|c|}
\hline Disposition & Frequency (f) & Percentage $(\%)$ \\
\hline Get Better & 49 & 79.0 \\
\hline Recovered & 3 & 4.8 \\
\hline Not Recovered & 10 & 16.1 \\
\hline
\end{tabular}

\section{Discussions}

Based on group of age, cruris fractures in children are highest at the age of senior high school (16-17 years old), that was supported by Rennie et al. ${ }^{6}$ in Edinburg, Scotland, they said that fracture incidence towards children are rises along with the ages growth. The high amount of cruris fracture accidents in senior high school ages often occur because nowdays high school students ride his own motor vehicles, particularly motorcycle so that the risk of incidents rises. ${ }^{7}$

Based on gender, Cruris fracture were dominated by male, supported by Mayranpaa et al. ${ }^{8}$ at Helsinki, Finland and Rennie et al. ${ }^{6}$ at Edinburg, Scotland. Boys were vulnerable to cruris fracture because boys tend to ride motorcycles than girls.

According to the period of time, fractures most often occur on April because Indonesia has a Monsoon season, where Java island is included on Region A, where the highest rainfall happens between November to March. ${ }^{9}$ According to data from Meteorological and Geophysical Agency of West Java ${ }^{10}$, the highest humidity occurs on April among other months, which can make the risk of accident and induce the fracture rises. ${ }^{11}$ Also on June, number of fracture accidents rises because of holiday season were held almost nationally, much traffic happens while children play outdoor so that the risk of cruris fracture accidents rises. On March, cruris fracture accidents is the least of all months, this is maybe because the patients prefer to go to indigenous medical practitioner or altenative medicine. ${ }^{3}$ Another possibility is the data which is missing from medical record.

According to fracture causes, most often it was caused by traffic accidents and falling down. This is related with Nwadinigwe et al. ${ }^{12}$, in Nigeria said that fractures in children was most often caused by traffic accidents then followed by falling down. This is also appropriate with one study in a certain hospital by Rennie et al. ${ }^{16}$ which said that one of the root causes of fracture at lower extremity in children are traffic accident. Nowadays traffic accidents often occur because almost every family own a motor vehicles, particularly motorcycle. Motor vehicles can cause the high number of accidents that caused fractures. ${ }^{13}$ The number of traffic accident cases in West Java are the third highest after East Java and Central Java. ${ }^{14}$ The most often traffic accident towards cruris fracture patients are motorcycle accidents then followed by accidents towards pedestrian. This study were related to Tandon et al. ${ }^{15}$ said that most often fracture's causes are accidents towards motorcycles then followed by accidents toward pedestrian.

The most often type of cruris fractures in child patients was open fractures. This result were related to Skaggs et al. ${ }^{16}$ who said that open fractures towards children were very often on tibia bones and fibula bones. Open fracture occured because of the location of tibia bones were subcutaneous ${ }^{4}$ and in this study, cruris fracture often occur because of traffic accidents which included in the injury with high pressure. ${ }^{17}$

According to fractured bones, tibia is often the location of cruris fracture. This is because there was no tendon or ligament that stick on the anteromedial surface of tibia, the surface was only subcutaneous. ${ }^{4}$ Fibula was the least occuring fracture because fibula is surrounded by tendon and fat tissues. ${ }^{11}$

Fractures location often occurs on the right side of lower extremity. The right lower extremity were more often fractured than the left. ${ }^{11,18}$ Cruris fractures often occur on the medial side of lower extremity. According to Herring, fractures on the medial of tibia and fibula most often occur in children. ${ }^{18}$ On the medial side there were shaft of tibia. Shaft of tibia is the thinest section of bones while the anterior side were the most prominent part, hence more prone to fractures. ${ }^{4,18}$

According to the patient's condition when they are taken away from the hospital, unrecovered condition may happen because of they disagreed with the treatment from the doctor, or the family wanted to look for other medical alternative ways.

As a conclusion, cruris fractures is found in high number in senior high school group 
and boys which are mostly caused by traffic accident. High number of open fractures, on tibia, on the right side and on the medial are also found with most of the patients are discharged in better condition. However, further studies are needed on cruris fracture in children in Indonesia, especially in West Java, using not only hospital-based data. Further studies on people's behavior in driving a motor vehicle are also needed. Moreover, parents are encouraged to advise their children in riding motorcycle and also communities should give counseling about the danger of cruris fracture in children. People should also be advised that when a fracture occurs, the patient should be immediately taken to the health service as soon as possible to avoid more severe fracture and complications

\section{References}

1. Badan Penelitian dan Pengembangan Kesehatan Departemen Kesehatan Republik Indonesia. Riset Kesehatan Dasar 2007. Jakarta: Departemen Kesehatan Republik Indonesia; 2008.

2. Ranuh ING. Cedera \& keracunan. In: Narendra MB, Sularyo TS, Soetjiningsih, Suyitno H, Ranuh ING, Wiradisuria S, editors. Tumbuh kembang anak dan remaja. 1st ed. Jakarta: Sagung Seto; 2005. p. 71-80.

3. Minhas MS, Ansari I, Khalid, Baig N, Siddiqui E. Musculo-Skeletal trauma and the epidemiology of fractures in children. J Pak Orthop Assoc. 2011;23(1):1-6.

4. Moore KL, Dalley AF, Agus AMR. Clinically oriented anatomy. 6th ed. Philadelphia: Lippincot Williams \& Wilkins; 2010.

5. Morrissy RT, Weinstein SL, editors. Lovell \& Winter's pediatric orthopaedics. 6th ed. Philadelphia: Lippincott Williams \& Wilkins; 2006.

6. Rennie L, Court-Brown CM, Mok JYQ Beattie TF. The epidemiology of fractures in children. Injury. 2007;38(8):913-22.

7. Sihaloho EB. Anak-anak sekolah: bebas dari aturan berkendara? 2012 [Cited 2012 November 22]: Available from: http://lifestyle.kompasiana.com/ catatan/2012/04/11/anak-anak-sekolahbebas-dari-aturan-berkendara/.

8. Mayranpaa MK, Makitie O, Kallio PE. Decreasing incidence and changing pattern of childhood fractures: a population-based study. J Bone Miner Res. 2010;25(12):2752-9.

9. Aldrian E, Susanto RD. Identification of three dominant rainfall regions within Indonesia and their relationship to sea surface temperature. Int J Climatol. 2003;23:1435-52.

10. Badan Perencanaan Pembangunan Jawa Barat. Jawa Barat Dalam Angka 2010. Bandung: Pemerintahan Propinsi Jawa Barat. 2010.

11. Beaty JH, Kasser JR. Rockwood and Wilkins Fractures in Children. 7th ed. Philadelphia: Lippincott Williams \& Wilkins; 2010.

12. Nwadinigwe CU, Ohezie CO, Iyidiobi EC. Fractures in Children. Nigerian Journal of Medicine. 2006;15(1):81-4.

13. Tripathi RB, Sah RP, Ali R, Bachhar B, Singh A. Clinico epidemiological study on pediatric fractures at Narayani Sub Regional Hospital, Birganj. Journal of GMCNepal. 2009;2(2):39-44.

14. Kementerian Kesehatan Republik Indonesia. Profil Data Kesehatan Indonesia Tahun 2011. Jakarta: Departemen Kesehatan Republik Indonesia; 2011.

15. Tandon T, Shaik M, Modi N. Paediatric trauma epidemiology in an urban scenario in India. J Orthop Surg. 2007;15(1):41-5.

16. 16. Skaggs DL, Friend L, Alman B, Chambers HG, Schmitz M, Leake B, et al. The effect of surgical delay on acute infection following 554 open fractures in children. J Bone Joint Surg. 2005;87:8-12.

17. David G, Stewart J, Kay RM, Skaggs DL. Open fractures in children: principal of evaluation and management. J Bone Joint Surg Am. 2005;87(12):2784-98.

18. Herring JA. Tachdjian's Pediatric Orthopaedics. 4th ed. Pennsylvania: Saunders; 2008. 